\title{
ANALISIS KEKERINGAN HIDROLOGI BERDASARKAN METODE NORMALIZED DIFFERENCE VEGETATION INDEX (NDVI) DI DAERAH ALIRAN SUNGAI ALANG KABUPATEN WONOGIRI
}

\author{
Mochammad Fajar Fadlillah ${ }^{(1)}$, Rintis Hadiani( ${ }^{(2)}$, dan Solichin ${ }^{(3)}$ \\ 1) Mahasiswa Fakultas Teknik, ProdiTeknik Sipil, Universitas Sebelas Maret J1. Ir. Sutami 36A, Surakarta 57126 \\ ${ }^{2)}$ Pengajar Fakultas Teknik, ProdiTeknik Sipil, Universitas Sebelas Maret Jl. Ir. Sutami 36A, Surakarta 57126 \\ Email:fadlilfajar@gmail.com
}

\begin{abstract}
Drought was yearly disaster which often happen at region of Indonesia. In this reseaech, we observe in Wonogiri especially Alang Watershed, located at southwest of Wonogiri dam and between Plumbon and Serenan district. The purpose of this research is to find the value of drought index using Normalized Difference Vegetation Index (NDVI). The drought is detected by using the debit. So, then created the relations of drought index and debit. Next, mapping the drought area in Alang watershed using software ArcGIS.

Collecting data is the first step of this research., then analyze the data and doing validation test using RAPS method. Calculating the rain area using polygon thiessen. NDVI value is obtained from processing the Landsat 7 and 8 image with Arcgis. Classifying NDVI value based on Peraturan Menteri Kehutanan RI nomor P.12/Menhut-II/2012. Calculating debit using NRECA. Then, creat the relation chart between drought index and debit. Mapping the drought area from the month which had lowest NDVI value and had lowest debit. Also mapping the drouht from 2008-2017.

knowing the drought area in Alang watershed and knowing the realtion chart between drought index and debit are the purpose of this research. The result showed that the relation chart of drouht index and debit aren't good to detecting the debit. The distribution of drought area is obtained from processing the Landsat 8 image with variative distribution and more accurate result.
\end{abstract}

Keywords: Normal Difference Vegetation Index (NDVI), drought, Alang watershed

\begin{abstract}
ABSTRAK
Kekeringan merupakan bencana tahunan yang sering terjadi di berbagai wilayah di Indonesia. Dalam penelitian ini, kami meninjau di Kabupaten Wonogiri khususnya di Daerah Aliran Sungai Alang. Daerah Aliran Sungai Alang berada di Kabupaten Wonogiri, tepatnya di sebelah barat daya Waduk Wonogiri dan diapit oleh Kecamatan Plumbon dan Serenan. Penelitian ini bertujuan untuk mengetahui nilai indeks kekeringan berdasarkan metode Normal Difference Vegetation Index (NDVI). Kekeringan juga dideteksi melalui debit. Lalu, membuat hubungan antara indeks kekeringan dengan debit yang terjadi. Kemudian dapat dipetakan wilayah kekeringan di DAS Alang menggunakan ArcGIS.

Pengumpulan data merupakan langkah awal penelitian ini, kemudian analisis data dan melakukan uji validitas data menggunakan metode RAPS. Perhitungan hujan wilayah menggunakan Polygon Thiesen. Nilai indeks vegetasi diperoleh dari pengolahan citra satelit Landsat 7 dan Landsat 8 yang kemudian diperoleh nilai NDVI menggunakan ArcGIS. Nilai NDVI tersebut dikelompokkan menurut Peraturan Menteri Kehutanan RI nomor P.12/MenhutII/2012. Perhitungan debit dilakukan dengan metode NRECA dan selanjutnya diperoleh nilai debit. Diperoleh hubungan antara indeks kekeringan dengan debit. Pemetaan persebaran luas kekeringan dilakukan pada bulan dengan debit terendah dan bulan dengan nilai NDVI terendah. Lalu, dilakukan pemetaan kekeringan dari tahun 2008 hingga 2017 menggunkan ArcGIS.

Mengetahui daerah kekeringan di DAS Alang dan memperoleh hubungan debit dengan indeks kekeringan merupakan tujuan dari penelitian ini. Hasil analisis menunjukkan bahwa grafik hubungan debit dan indeks vegetasi tidak baik untuk mendeteksi besarnya debit. Luasan persebaran kekeringan dapat diperoleh dari olahan citra Landsat 8 dengan sebaran yang variatif dan hasil yang lebih akurat.
\end{abstract}

Kata kunci: Normal Difference Vegetation Index (NDVI), Indeks Vegetasi, Kekeringan, DAS Alang 


\section{PENDAHULUAN}

kekeringan adalah ketersediaan air yang jauh di bawah dari kebutuhan air untuk kebutuhan hidup, pertanian, kegiatan ekonomi dan lingkungan. Penyempitan lahan dan kekeringan menjadi permasalahan lingkungan yang dialami di berbagai daerah di bumi ini. Beralihnya fungsi lahan, bantaran sungau dan hutan menjadi pemukiman menjadi penyebab ketidakseimbangan ekosistem sehingga menimbulkan dampak lingkungan. Salah satu dampak lingkungan tersebut adalah kekeringan.

Kekeringan ini berkaitan dengan berkurangnya pasokan air permukaan dan air tanah. Kekeringan hidrologis diukur dari ketinggian muka air waduk, danau dan air tanah. Ada jarak waktu antara berkurangnya curah hujan dengan berkurangnya ketinggian muka air sungai, danau dan air tanah, sehingga kekeringan hidrologis bukan merupakan gejala awal terjadinya kekeringan.

Wonogiri merupakan salah satu kabupaten yang terletak di Provinsi Jawa Tengah. Daerah ini yang memiliki curah hujan rendah sehingga berpengaruh pada ketersediaan air yang selanjutnya mengakibatkan bencana kekeringan terutama pada bulan kering atau musim kemarau. Salah satu Derah Aliran Sungai (DAS) yang terdampak bencana kekeringan karena defisit air yaitu Daerah Aliran Sungai (DAS) Alang.

Informasi dan data tentang kondisi keadaan permukaan sangat dibutuhkan. Informasi spasial suatu wilayah dapat diperoleh menggunakan data penginderaan jauh dan SIG dalam ekstraksi informasi mengenai keruangan dan kewilayahan secara menyeluruh dan hubungannya dengan sumber daya air. SIG dapat memodelkan permukaan bumi dalam bentuk nyata (tiga dimensi). Data penginderaan jauh berupa Citra Landsat digunakan untuk mengidentifikasi kerapatan vegetasi. Kerapatan vegetasi diidentifikasi dengan transformasi Normalized Difference Vegetation Index (NDVI).

Dengan mengaitkan berbagai parameter yang memicu terjadinya kekeringan maka dapat diidentifikasi wilayah yang berpotensi mengalami kekeringan. Tujuan dari penelitian ini adalah mengidentifikasi potensi daerah kekeringan di DAS Alang dan kemudian dapat dibuat peta tematik persebaran wilayah potensi kekeringan menggunakan aplikasi ArcGIS.

\section{LANDASAN TEORI}

Terdapat beberapa metode yang dapat digunakan untuk menganalisis kekeringan, antara lain yaitu Standardized Precipitation Index (SPI), Surface Water Index (SWI), Palmer, Vegetasi Condition Index, Moisture Adequacy Index, dan masih banyak lagi. Pada penelitian di DAS Alang ini menggunakan metode Normalized Difference Vegetation Index (NDVI).

Indeks vegetasi adalah indeks yang menggambarkan tingkat kehijauan suatu tanaman. Indeks vegetasi merupakan kombinasi matematis antara band merah dan band NIR (Near-Infrared Radiation) yang telah lama digunakan sebagai indikator keberadaan dan kondisi vegetasi (Lillesand dan Kiefer 1997).

Semakin rendah nilai NDVI, tingkat kerawanan terhadap kekeringan akan semakin tinggi, sebaliknya, nilai NDVI yang tinggi menunjukkan daerah tersebut mempunyai tingkat kerawanan terhadap kekeringan yang tergolong rendah (Muharrama Putra Prayoga, 2017).

\section{Mengisi Data Hujan yang Hilang}

Data hujan yang diperoleh dari stasiun pengamatan terkadang tidak tersedia secara lengkap. Pengisian data hujan hilang pada penelitian ini menggunakan reciprocal method. Metode ini memanfaatkan jarak antar stasiun sebagai faktor koreksi (weighting factor). Korelasi antar dua stasiun hujan akan menjadi semakin kecil apabila jarak antar stasiun semakin besar. Mengisi data hujan yang hilang dihitung dengan Persamaan 1.

$\boldsymbol{P} \boldsymbol{x}=\frac{\sum_{i=1}^{n} \frac{P_{i}}{L_{i}^{2}}}{\sum_{i=1}^{n} \frac{1}{L_{i}^{2}}}$

dengan:

$P x=$ data curah hujan pada stasiun $\mathrm{X}$ yang diperkirakan data hilang,

$P_{i} \quad=$ data hujan disekitarnya pada periode yang sama, dan

$L_{i} \quad=$ jarak antar stasiun. 


\section{Uji Konsistensi Data}

Data yang diperoleh dari alat pencatat bisa jadi tidak panggah karena: alat pernah rusak, alat pernah pindah tempat, lokasi alat terganggu, atau terdapat data tidak sah. Uji konsistensi dapat dilakukan dengan lengkung massa ganda (double mass curve) untuk stasiun hujan $\geq 3$ (tiga), dan untuk individual stasiun (stand alone station) dengan cara RAPS (Rescaled Adjusted Partial Sums), Sri Harto (2000). Bila yang didapat lebih kecil dari nilai kritik untuk tahun dan confidence level yang sesuai, maka data dinyatakan panggah.

\section{Hujan Wilayah}

Data hujan yang diperoleh dari stasiun pengamatan hujan merupakan data hujan yang terjadi disuatu tempat atau titik saja (point rainfall). Hujan sangat bervariasi terhadap tempat, maka satu stasiun belum bisa menggambarkan hujan yang terjadi pada suatu wilayah. Metode Thiessen merupakan metode yang memperhitungkan bobot dari masing-masing stasiun yang mewakili luasan di sekitarnya. Metode ini menganggap bahwa hujan yang terjadi pada suatu stasiun mempunyai pengaruh yang dibatasi oleh poligon Thiessen. Metode Thiessen digunakan apabila penyebaran stasiun hujan di wilayah yang ditinjau tidak merata (Bambang Triatmodjo, 2008).

Perhitungan hujan wilayah dengan metode Poligon Thiessen dapat menggunakan Persamaan 2 berikut.

$\bar{p}=\frac{A_{1} p_{1}+A_{2} p_{2}+\cdots+A_{n} p_{n}}{A_{1}+A_{2}+\cdots+A_{n}}$ dengan:

$\mathrm{p} \quad=$ hujan rerata kawasan,

$\mathrm{p}_{1}, \mathrm{p}_{2}, \ldots \mathrm{p}_{\mathrm{n}} \quad=$ hujan di stasiun $1,2,3, \ldots . \mathrm{n}$, dan

$\mathrm{A}_{1}, \mathrm{~A}_{2}, \ldots \mathrm{A}_{\mathrm{n}} \quad=$ luas daerah yang mewakili stasiun $1,2, \ldots \mathrm{n}$.

\section{Evapotranspirasi Potensial}

Evapotranspirasi merupakan banyaknya air yang dipergunakan untuk proses pertumbuhan tanaman (transpirasi) dan evaporasi dari tanah/ air sebagai tempat tumbuhnya tanaman tersebut (SNI 7745 : 2012). Perhitungan evaporasi potensial metode Penman-moenteith dapat dilakukan melalui software cropwatt 8.0.

\section{Simulasi hujan debit dengan Metode NRECA}

Tahapan perhitungan debit dengan Metode NRECA adalah sebagai berikut :

$$
\begin{array}{ll}
Q & =D F+G W F \\
D F & =E M-G W S \\
G W F & =P_{2} \times G W S \\
G W S & =P_{1} \times E M \\
S & =W B-E M \\
E M & =E M R \times W B \\
W B & =R b-A E T \\
A E T & =\frac{A E T}{P E T} \times P E T \\
W i & =\frac{W o}{N} \\
N & =100+0,20 R a \\
\text { dengan } & :
\end{array}
$$

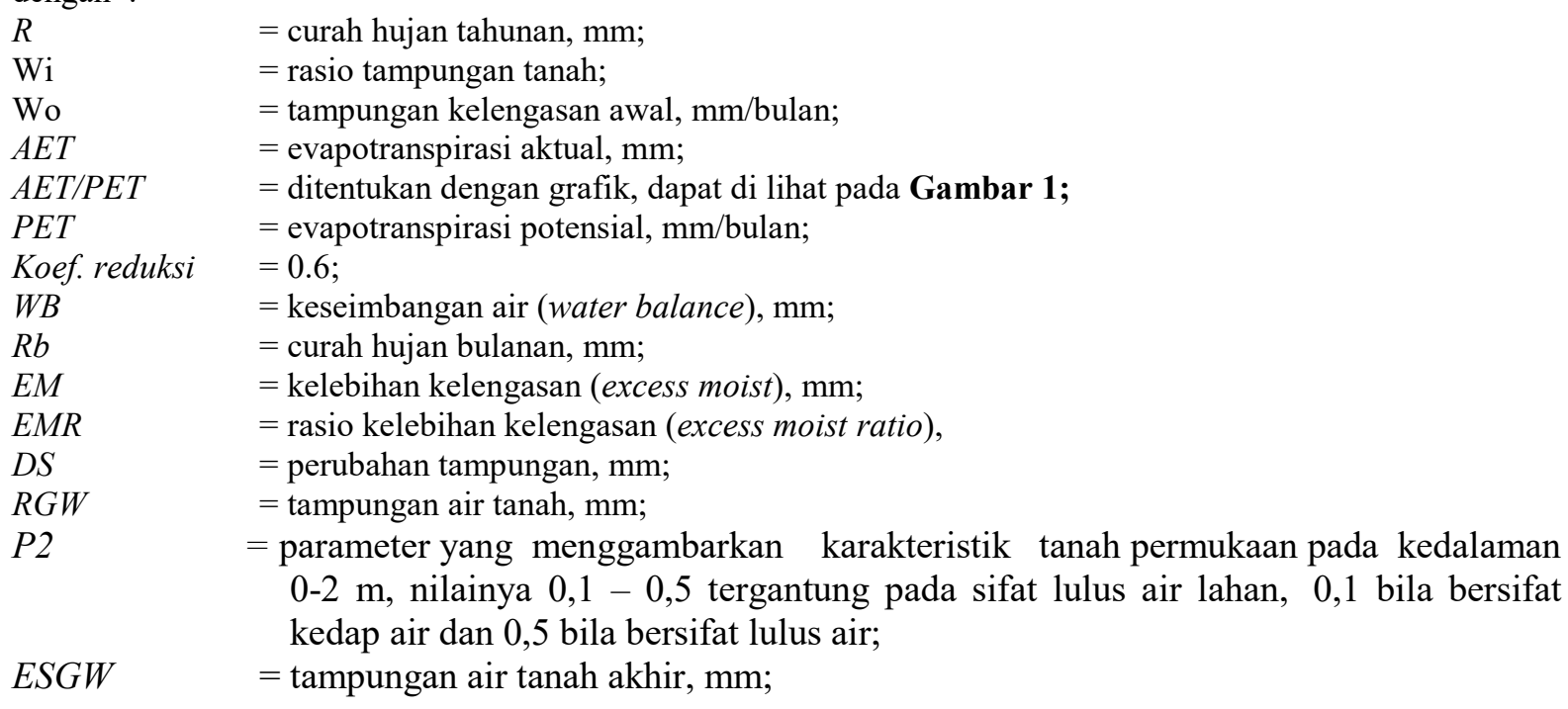




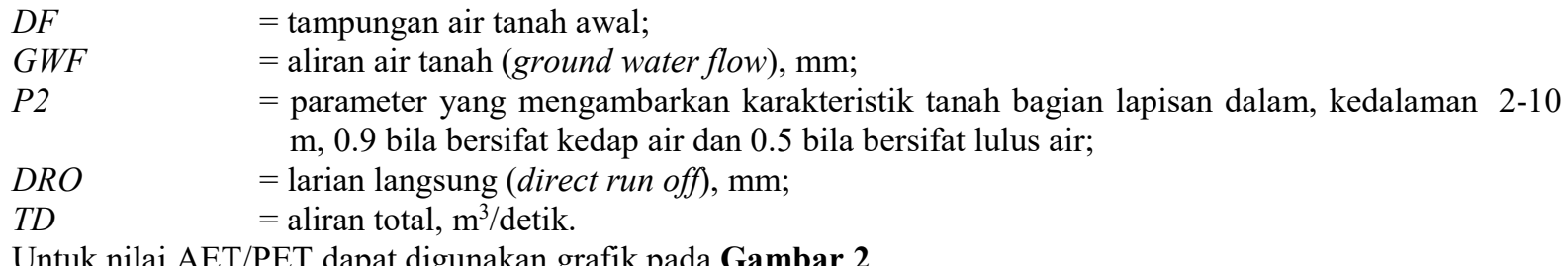

Untuk nilai AET/PET dapat digunakan grafik pada Gambar 2.

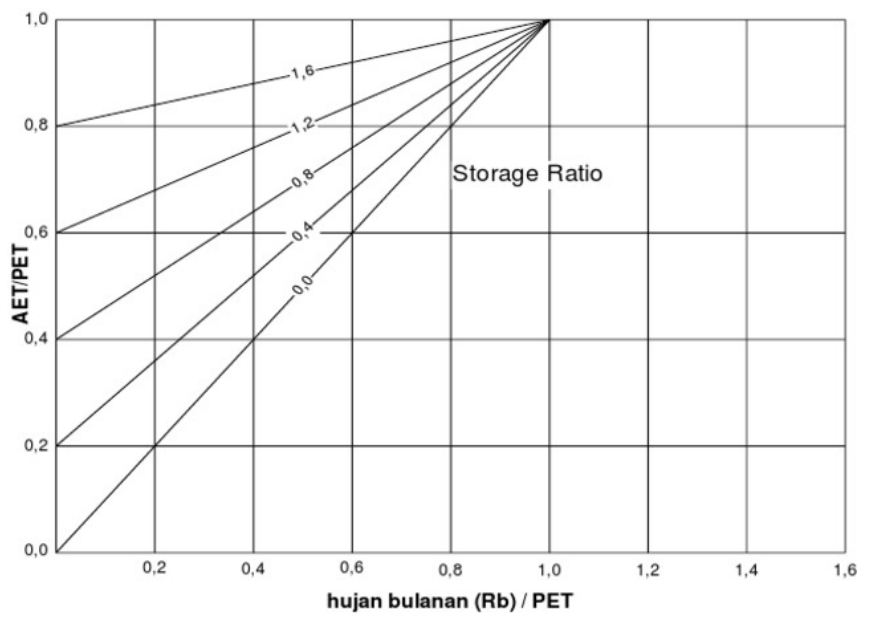

(Sumber : KP-Jaringan Irigasi 01)

Gambar 1. Grafik nilai AET/PET

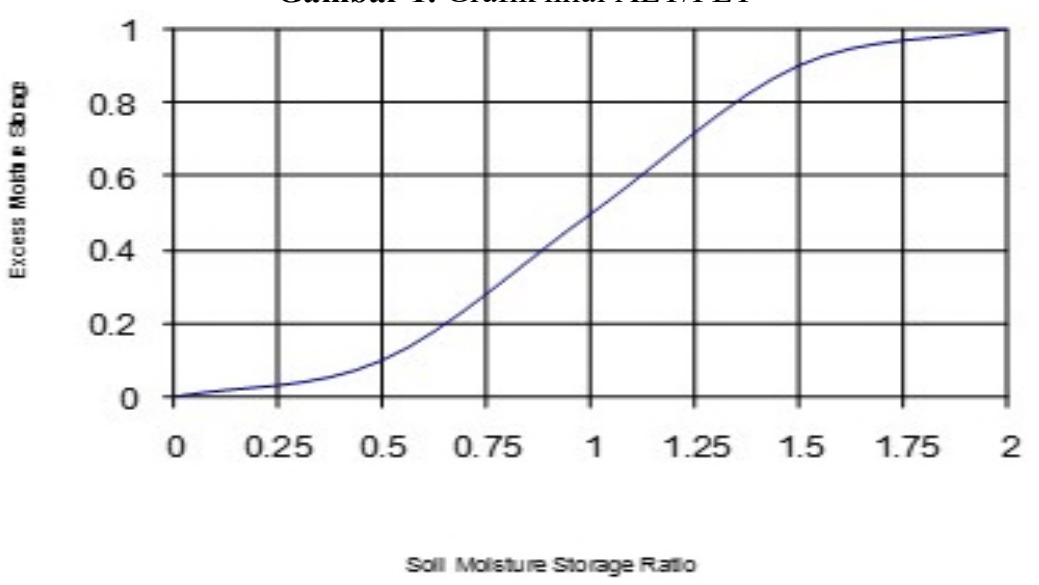

(Sumber : KP-Jaringan Irigasi 01)

Gambar 2. Grafik Rasio Tampungan Kelengasan Tanah

\section{Transformasi Citra}

Transformasi citra merupakan upaya untuk menonjolkan salah satu obyek dan menekan aspek yang lain. Transformasi citra yang digunakan pada penelitian ini berupa teknik Normalized Difference Vegetation Index (NDVI).

\section{Indeks Vegetasi}

NDVI merupakan kombinasi antara teknik penisbahan dengan teknik pengurangan citra. Indeks ini sederhana dan mempunyai nilai range yang dinamis dan sensitif yang paling bagus terhadap perubahan tutupan vegetasi. Saluran yang digunakan dalam transformasi ini adalah saluran merah dan inframerah. Kedua saluran ini dipilih karena memiliki kepekaan yang berbeda terhadap vegetasi.

\section{Sistem Informasi Geografis (SIG)}

Sistem Informasi Geografis (SIG) adalah sistem dengan basis komputer yang digunakan untuk menyimpan dan memanipulasi informasi geografi. Sistem Informasi Geografis dirancang untuk mengumpulkan, menyimpan dan menganalisa obyek-obyek dan fenomena dimana lokasi geografi merupakan karakteristik yang penting atau kritis untuk dianalisis (Aronoff, 1989). Terdapat empat kemampuan yang dimiliki sistem informasi geografis 
dalam menangani data yang bereferensi secara geografi, yaitu: pemasukan data, manajemen (penyimpanan danpemanggilan data), analisis dan manipulasi data, serta keluaran data.

\section{Nilai NDVI}

Indeks vegetasi atau NDVI adalah indeks yang menggambarkan tingkat kehijauan suatu tanaman. Indeks vegetasi merupakan kombinasi matematis antara band merah dan band NIR (Near-Infrared Radiation) yang telah lama digunakan sebagai indikator keberadaan dan kondisi vegetasi (Lillesand dan Kiefer 1997).

$N D V I=(N I R-R e d) /(N I R+R e d)$

dengan :

$N I R=$ kanal radiasi inframerah dekat dari piksel,

Red = kanal radiasi cahaya merah dari piksel,

Nilai NDVI berkisar dari -1 (yang biasanya air) sampai +1 (vegetasi lebat).

\section{Indeks Kekeringan berdasarkan Nilai NDVI}

Kriteria kekeringan dapat ditentukan berdasarkan Hasil pengolahan menggunakan algoritma NDVI dengan menggunakan band red dan band NIR sehingga diperoleh nilai NDVI. Nilai-nilai tersebut dikelompokkan ke dalam 5 kelas menurut Peraturan Menteri Kehutanan RI nomor P.12/Menhut-II/2012. Seperti pada Tabel 1.

Tabel 1 Nilai NDVI

\begin{tabular}{lll}
\hline Kelas & NDVI & Keterangan \\
\hline 1 & $-1 \mathrm{~s} / \mathrm{d}-0,03$ & Lahan tidak bervegetasi \\
\hline 2 & $-0,03 \mathrm{~s} / \mathrm{d} 0,15$ & Kehijauan sangat rendah \\
\hline 3 & $0,15 \mathrm{~s} / \mathrm{d} 0,25$ & Kehijauan rendah \\
\hline 4 & $0,26 \mathrm{~s} / \mathrm{d} 0,35$ & Kehijauan sedang \\
\hline 5 & $0,36 \mathrm{~s} / \mathrm{d} 1,00$ & Kehijauan tinggi \\
\hline
\end{tabular}

(Sumber : Peraturan Menteri Kehutanan Republik Indonesia Nomor P.23/Menhut-II/2012, 2012)

\section{Grafik Hubungan antara Indeks Kekeringan dengan Debit}

Dengan debit yang diperoleh dari Metode NRECA dan nilai NDVI yang diperoleh dari pengolahan citra yang kemudian dikelopokkan dalam indeks kekeringan maka dapat dibuat grafik hubungan antara debit dengan indeks kekeringan. Sehingga dapat diketahui daerah yang mengalami kekeringan memiliki debit sekian dan begitu sebaliknya, daerah dengan debit sekian mengalami kekeringan dengan kategori tertentu.

\section{Pemetaan Persebaran Luas Kekeringan}

Berdasarkan hasil transformasi citra yang berupa NDVI, sehingga diperoleh tingkat kekeringan masing-masing daerah. Untuk menghitung luas tiap kelas kekeringan, digunakan fitur calculate geometry yang mampu menghitung luasan poligon.

\section{METODE PENELITIAN}

Metode yang digunakan dalam penelitian ini adalah metode Normalized Difference Vegetation Index (NDVI). Dari nilai NDVI diperoleh indeks kekeringannya kemudian dilakukan pembuatan grafik hubungan antara indeks dan dbit serta dilakukan pemetaan luas persebaran kekeringan dengan ArcGIS.Penelitian dilakukan di DAS Alang Kabupaten Wongriri.

Data yang digunakan adalah:

1. Peta DAS Alang diperoleh dari Data PUSDATARU Solo 2018.

2. Citra Landsat di DAS Alang.

3. Data curah hujan dari 3 stasiun hujan dari tahun 2008-2017.

4. Data Klimatologi Wonogiri dari tahun 2008-2017.

Data di atas kemudian diolah dengan menggunakan bebrapa perangkat digital yang terdiri dari:

1. Miscrosof Word untuk menyusun laporan skripsi.

2. Miscrosof Excel untuk pengolahan data hujan dan analisis hidrologi.

3. Cropwatt untuk mengetahui evapotranspirasi potensial.

4. ArcGIS 10.3 untuk analisis data spasial dan pemetaan peta persebaran kekeringan. 


\section{HASIL DAN PEMBAHASAN}

\section{Simulasi Hujan-Debit Menggunakan NRECA}

Tahapan perhitungan simulasi hujan-debit dengan metode NRECA pada bulan Januari 2008 sebagai berikut:

1. Jumlah hari $=31$

2. Data Curah Hujan $(\mathrm{P}) \quad=154,1695 \mathrm{~mm} / \mathrm{hari}$

3. Data Evapotranspirasi $=67,27 \mathrm{~mm} / \mathrm{hari}$

4. ET0

$=67,27 \mathrm{~mm} /$ hari

- $\quad$ Apabila evapotranspirasi $<$ curah hujan maka ET0 = evapotranspirasi

- Apabila evapotranspirasi $>$ curah hujan maka ET0 $=$ curah hujan, jika curah hujan $=0$, maka ET0 = 5

5. Tampungan kelengasan awal $=$ Wo $(\mathrm{SMC}) \quad=450$ (trial),

(bulan selanjutnya dengan Rumus = Wo bulan sebelumnya + Delta Storage bulan sebelumnya)

6. Tampungan kelengasan $=\mathrm{Wi}$

$$
\begin{aligned}
& =\frac{W o}{100+(0,2 \times \text { P total })} \\
& =\frac{W o}{100+(0,2 \times P \text { total })} \\
& =\frac{450}{100+(0,2 \times 1584,5798)}
\end{aligned}
$$

7. $\frac{R b}{E T 0} \quad=154,1695 / 67,27=2,29$

8. $\frac{A E T}{E T 0}=1$, lihat grafik pada Gambar 1

9. Evapotranspirasi aktual $=\mathrm{AET}=0,9 \times \frac{A E T}{E T 0} \times \mathrm{ET} 0$

$$
=0,9 \times 1 \times 67,27=60,5430 \mathrm{~mm}
$$

10. Water balance

$=\mathrm{P}-\mathrm{AET}=154,1695-60,5430=93,6265 \mathrm{~mm}$

11. Moist ratio

$=$ Neraca air positif $(+)$, maka rasio $=0,546$, lihat grafik pada Gambar 2

12. Excess moist $=$ water balance $x$ excess moist

13. Delta storage

$$
=93,6265 \times 0,546=51,1200 \mathrm{~mm}
$$

$=$ water balance - excess moist

$$
=93,6265-51,1200=42,5064 \mathrm{~mm}
$$

14. Ground water storage (GWS) $=0,8 \times$ excess moist $=0,8 \times 51,1200=40,8961 \mathrm{~mm}$

15. Direct flow (DF) = 2 (trial),

(bulan selanjutnya dengan Rumus = End storage ground water bulan sebelumnya - GWF bulan sebelumnya)

16. End storage ground water = Ground water storage (GWS) +Direct flow (DF)

$=40,8961+2=42,8961 \mathrm{~mm}$

17. Ground water flow (GWF) $=0,2 \times$ End storage ground water

$=0,2 \times 42,8961=8,5792 \mathrm{~mm}$

18. Dierct run off

= Excess moist - Ground water storage (GWS)

19. Total run off $=51,1200-40,8961=10,2240 \mathrm{~mm}$

$=$ Ground water flow $(\mathrm{GWF})+$ Dierct run off

$=8,5792+10,2240=18,8032 \mathrm{~mm}$

20. Total run off $\left(\mathrm{m}^{3} /\right.$ detik $)$

$$
\begin{aligned}
& =\frac{\text { Totol run of } f \times 0,001}{3600 \times 24 \times 31} \times \text { luas } \times 10 \\
& =\frac{18,8032 \times 0,001}{3600 \times 24 \times 31} \times 13146,36 \times 10
\end{aligned}
$$

$=0,9229 \mathrm{~m}^{3} /$ detik

Tahapan selanjutnya perhitungan simulasi hujan-debit metode NRECA dilakukan terhadap data hujan bulanbulan berikutnya dengan tahapan yang sama.

\section{Perhitungan Indeks Kekeringan Berdasarkan Metode NDVI}

Normalized Difference Vegetation Index (NDVI) atau Indeks Vegetasi merupakan alat ukur yang digunakan untuk mengetahui kerapatan vegetasi di suatu daerah dengan cara menganalisa pada nilai kecerahan digital. Nilai kecerahan digital dipengaruhi oleh gelombang yang diterima oleh alat rekam digital dalam hal ini adalah satelit Landsat. Gelombang akibat sinar matahari terdiri dari berbagai jenis gelombang yang mana jatuh pada 
permukaan daun-daun tanaman. Sebagian digunakan untuk fotosintesis dengan cara diserap, sedangkan sebagian lain dipantulkan kembali. Gelombang pantulan inilah yang digunakan untuk analisis kerapatan vegetasi pada suatu daerah.

Vegetasi yang sehat menyerap banyak gelombang sinar tampak (Infrared) dan memantulkan gelombang sinar Near-infrared dalam jumlah banyak .

Secara matematis perhitungan NDVI dapat dihitung dengan persamaan (2.43), dengan bantuan ArcGIS nilai NDVI dapat diperoleh melalui pegolahan citra satelit.

Data yang diperoleh berupa Landsat 7 dan Landsat 8, pengolahan masing-masing citra Landsat berbeda.

\section{Klasifikasi Kekeringan}

Semakin kecil nilai NDVI semakin besar potensi kekeringan yang terjadi pada daerah tersebut, begitu pula semakin tinggi nilai NDVI menggambarkan semakin kecil poternsi kekeringan pada daerah tersebut. Dari pernyataan tersebut dapat diklasifikasikan kategori kekeringan berdasarkan indeks vegetasi. Seperti pada Tabel 2.

Tabel 2 Indeks Kekeringan Berdasarkan NDVI

\begin{tabular}{lll}
\hline Kelas & NDVI & Keterangan \\
\hline 1 & $-1 \mathrm{~s} / \mathrm{d}-0,03$ & Sangat Kering \\
\hline 2 & $-0,03 \mathrm{~s} / \mathrm{d} 0,15$ & Kering \\
\hline 3 & $0,15 \mathrm{~s} / \mathrm{d} 0,25$ & Agak Kering \\
\hline 4 & $0,25 \mathrm{~s} / \mathrm{d} 0,35$ & Basah \\
\hline 5 & $0,35 \mathrm{~s} / \mathrm{d} 1,00$ & Sangat Basah \\
\hline
\end{tabular}

\section{Grafik}

Grafik hubungan antara indeks dan debit di DAS Alang membentuk sebuah kurva dengan persamaan power yang nantinya persamaan ini dapat digunakan untuk menentukan berapa perkiraan besarnya debit jika terlebih dahulu diketahaui indeksnya. Persamaan yang dihasilkan yaitu $y=7,7464 \mathrm{x}^{1,6197}$ dengan $\mathrm{R}^{2}$ yaitu 0,1238 . Seperti pada Gambar 4.

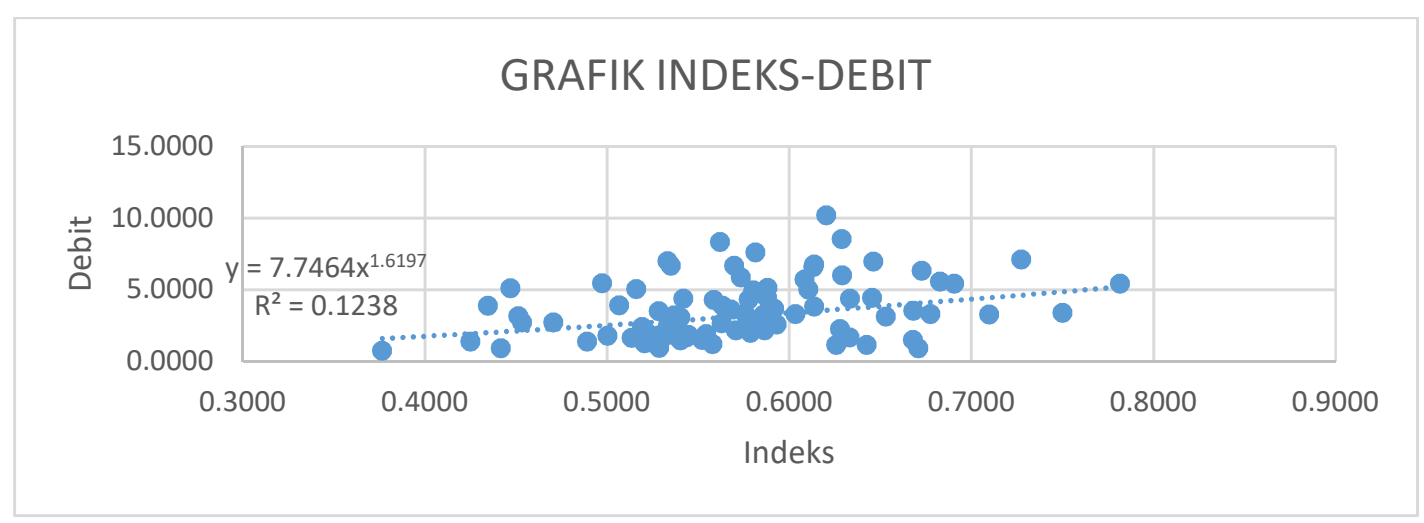

Gambar 3. Grafik Hubungan Indeks dan Debit

\section{Pemetaan Persebaran Luas Kekeringan}

Pemetaan persebaran luas kekeringan dilakukan mengunakan aplikasi ArcGIS. Perhitungan luas persebaran kekeringan dilakukan pada debit terkecil dan nilai indeks kekeringan terkecil pada masing-masing citra Landsat 7 dan Landsat 8.

Debit terendah dengan citra Landsat 7 terjadi pada bulan September 2008. Debit terendah dengan citra Landsat 8 terjadi pada bulan Oktober 2014. Nilai indeks kekeringan terendah dengan citra Landsat 7 terjadi pada bulan September 2012. Nilai indeks kekeringan terendah dengan citra Landsat 8 terjadi pada bulan Juli 2015.

Hasil Perhitungan dan perseberannya dapat dilihat pada Gambar 4. 


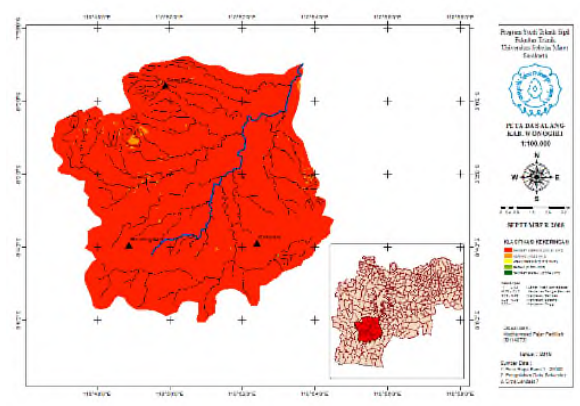

Debit terendah dengan citra Landsat 7 7

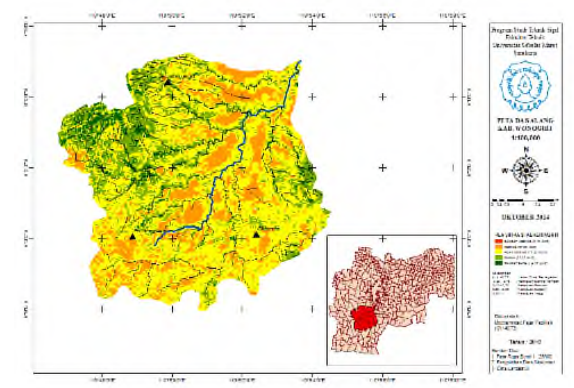

Debit terendah dengan citra Landsat 8

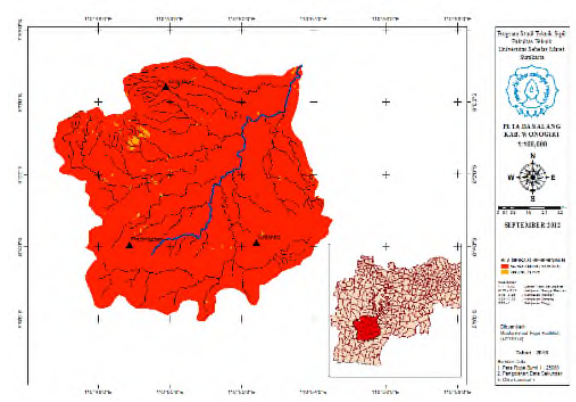

Indeks Kekeringan terendah dengan citra Landsat

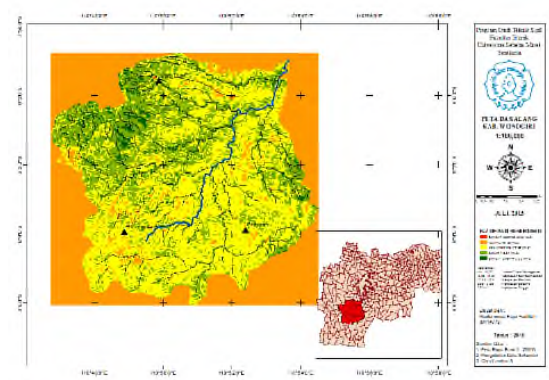

Indeks Kekeringan terendah dengan citra Landsat 8

Gambar 4. Pemetaan Persebaran Luas Kekeringan

Dihasilkan persebaran luas kekeringan sebagai berikut :

1. Luas persebaran kekeringan berdasarkan debit terendah menggunakan Landsat 7 (September 2008)

Luasan sangat kering $: 130,5112 \mathrm{~km}^{2}$

Luasan kering $\quad: 0,9185 \mathrm{~km}^{2}$

Luasan agak kering $\quad: 0,0134 \mathrm{~km}^{2}$

Luasan sangat kering : $0,0049 \mathrm{~km}^{2}$

Luasan sangat kering : $0,0036 \mathrm{~km}^{2}$

2. Luas persebaran kekeringan berdasarkan debit terendah menggunakan Landsat 8 (Oktober 2014)

Luasan sangat kering $: 0,1155 \mathrm{~km} 2$

Luasan kering $\quad: 27,0788 \mathrm{~km} 2$

Luasan agak kering $\quad: 72,2235 \mathrm{~km} 2$

Luasan sangat kering $: 27,5231 \mathrm{~km} 2$

Luasan sangat kering : $4,5745 \mathrm{~km} 2$

3. Luas persebaran kekeringan berdasarkan indeks kekeringan terendah menggunakan Landsat 7 (September 2012)

Luasan sangat kering $: 130,2645 \mathrm{~km} 2$

Luasan kering $\quad: 1,1938 \mathrm{~km} 2$

Luasan agak kering $\quad: 0,00 \mathrm{~km} 2$

Luasan sangat kering : $0,00 \mathrm{~km} 2$

Luasan sangat kering : $0,00 \mathrm{~km} 2$

4. Luas persebaran kekeringan berdasarkan indeks kekeringan terendah menggunakan Landsat 8 (Juli 2015)

Luasan sangat kering : $0,0166 \mathrm{~km} 2$

Luasan kering $\quad: 5,5649 \mathrm{~km} 2$

Luasan agak kering $\quad: 75,9881 \mathrm{~km} 2$

Luasan sangat kering : $45,5679 \mathrm{~km} 2$

Luasan sangat kering : $4,3260 \mathrm{~km} 2$

Dari hasil luasan persebaran kekeringan yang diperoleh dari citra Landsat 7 menghasilkan persebaran kekeringan yang tidak bervariasi dan tidak akurat. sedangkan hasil luasan persebaran kekeringan yang diperoleh dari citra Landsat 8 menghasilkan persebaran kekeringan yang bervariasi dan rentang nilai yang lebih banyak serta keakuratan lebih baik daripada Landsat 7. 


\section{Pemetaan Kekeringan}

Indeks yang diperoleh berasal dari peta hasil olahan citra Landsat. Pemetaan indeks kekeringan menggunakan

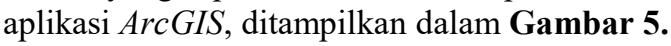

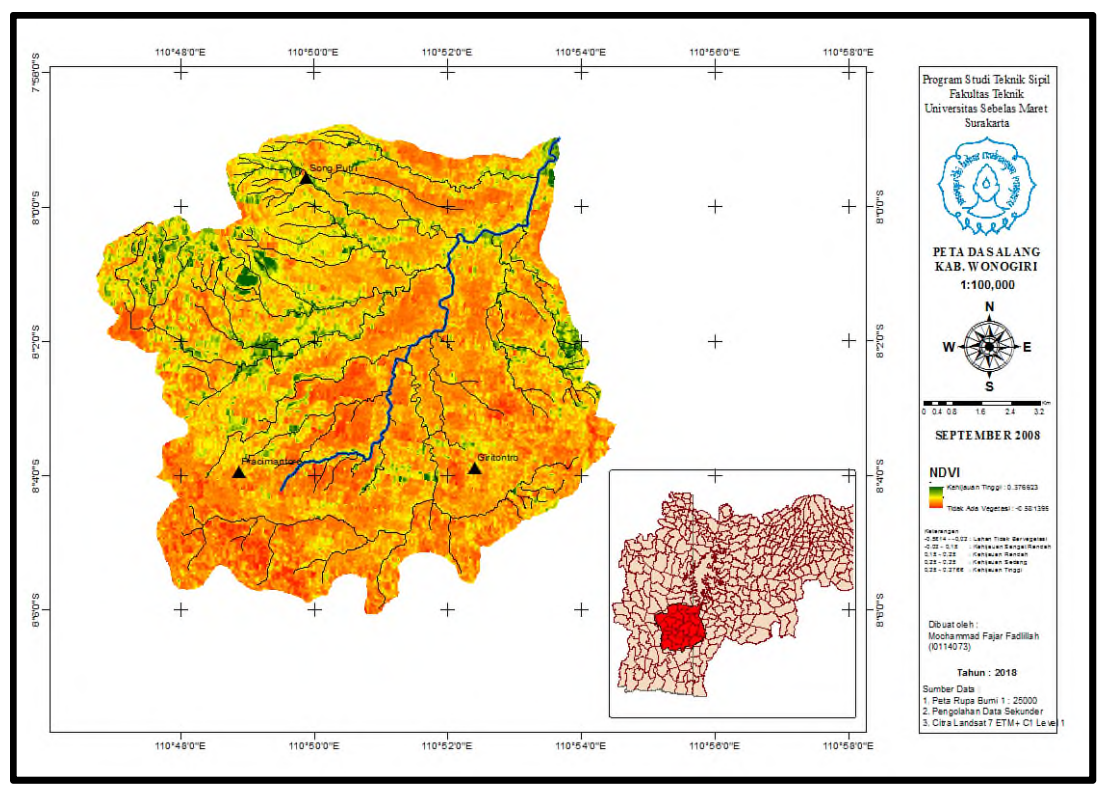

Gambar 5. Pemetaan Kekeringan Bulan September 2008

Indeks diperoleh dari nilai NDVI maksimum. Diambil nilai maksimum dikarenakan jika ada awan atau kabut yang terekam oleh citra, maka dapat dipastikan nilai NDVI maksimum terseubut bukan merupakan nilai NDVI pada awan atau kabut. Nilai indeks terendah pada tahun 2008 adalah pada bulan September.

Untuk pemetaan tahunan ditampilkan dalam Gambar 6.

Pemetaan kekeringan tahun 2008

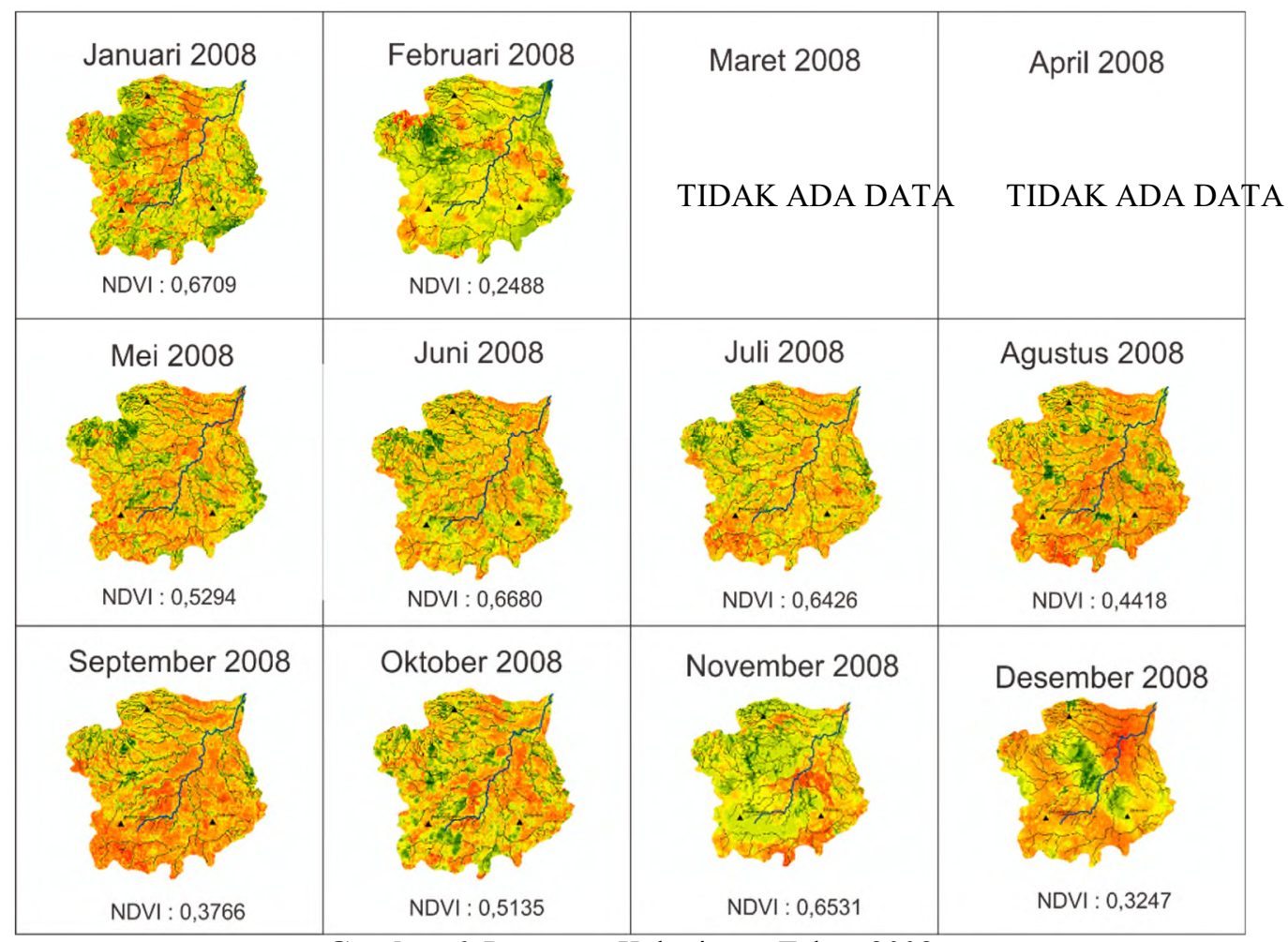

Gambar 6. Pemetaan Kekeringan Tahun 2008 


\section{SIMPULAN}

Berdasarkan penelitian yang sudah dilakukan, dapat ditarik beberapa kesimpulan, yang terdiri dari:

1. Nilai radiasi saluran merah (RED) dan infra merah (NIR) diperoleh dari saluran 3 dan 4 untuk citra Landsat 7 sedangkan Landsat 8 diperoleh dari saluran 4 dan 5 yang diproses menggunakan ArcGIS.

2. Grafik hubungan antara debit dan indeks menghasilkan persamaan yaitu $y=7,7464 x^{1,6197}$ dengan $R^{2}$ yaitu 0,1238 dengan sumbu y adalah debit dan $\mathrm{x}$ adalah indeks. Dengan nilai korelasi yang rendah maka dapat disimpulkan bahwa pencarian nilai indeks dengan metode NDVI tidak cocok untuk mendeteksi debit. Hal ini dikarenakan parameter indeks yang sama sekali tidak melibatkan parameter debit seperti curah hujan, evapotranspirasi maupun besarnya debit, melainkan hanya murni dari citra satelit saja.

3. Pemetaan persebaran luas kekeringan dilakukan pada debit terendah dan indeks kekeringan terendah untuk masing-masing citra Landsat 7 dan Landsat 8. Dihasilkan persebaran luas kekeringan sebagai berikut :

1. Luas persebaran kekeringan berdasarkan debit terendah menggunakan Landsat 7 (September 2008)
Luasan sangat kering
: $130,5112 \mathrm{~km}^{2}$
Luasan kering
: $0,9185 \mathrm{~km}^{2}$
Luasan agak kering
: $0,0134 \mathrm{~km}^{2}$
Luasan sangat kering
: $0,0049 \mathrm{~km}^{2}$
Luasan sangat kering
: $0,0036 \mathrm{~km}^{2}$

2. Luas persebaran kekeringan berdasarkan debit terendah menggunakan Landsat 8 (Oktober 2014)

Luasan sangat kering $\quad: 0,1155 \mathrm{~km}^{2}$

Luasan kering : :27,0788 $\mathrm{km}^{2}$

Luasan agak kering $\quad: 72,2235 \mathrm{~km}^{2}$

Luasan sangat kering $\quad: 27,5231 \mathrm{~km}^{2}$

Luasan sangat kering $\quad: 4,5745 \mathrm{~km}^{2}$

3. Luas persebaran kekeringan berdasarkan indeks kekeringan terendah menggunakan Landsat 7 (September 2012)

$\begin{array}{ll}\text { Luasan sangat kering } & : 130,2645 \mathrm{~km}^{2} \\ \text { Luasan kering } & : 1,1938 \mathrm{~km}^{2} \\ \text { Luasan agak kering } & : 0,00 \mathrm{~km}^{2} \\ \text { Luasan sangat kering } & : 0,00 \mathrm{~km}^{2} \\ \text { Luasan sangat kering } & : 0,00 \mathrm{~km}^{2}\end{array}$

4. Luas persebaran kekeringan berdasarkan indeks kekeringan terendah menggunakan Landsat 8 (Juli 2015)

Luasan sangat kering $\quad: 0,0166 \mathrm{~km}^{2}$

Luasan kering $\quad: 5,5649 \mathrm{~km}^{2}$

Luasan agak kering $\quad: 75,9881 \mathrm{~km}^{2}$

Luasan sangat kering $\quad: 45,5679 \mathrm{~km}^{2}$

Luasan sangat kering $\quad: 4,3260 \mathrm{~km}^{2}$

Dari hasil luasan persebaran kekeringan yang diperoleh dari citra Landsat 7 menghasilkan persebaran kekeringan yang tidak bervariasi dan tidak akurat. sedangkan hasil luasan persebaran kekeringan yang diperoleh dari citra Landsat 8 menghasilkan persebaran kekeringan yang bervariasi dan rentang nilai yang lebih banyak serta keakuratan lebih baik daripada Landsat 7. Sehingga untuk mengetahui luasan persebaran lebih baik menggunakan citra Landsat 8 karena memiliki ketajaman citra yang lebih tinggi.

4. Pemetaan kekeringan dari tahun 2008-2017 dilakukan dengn mengolah citra Landsat 7 dan Landsat 8 menggunakan aplikasi ArcGIS. Citra yang diperoleh kemudian diolah dan dicari nilai NDVI nya menggunakan tool NDVI yang sudah tersedia di aplikasi tersebut. Warna yang digunakan adalah gradasi warna hijau ke kuning lalu ke merah untuk mewakili tingkat kerapatan vegetasi di Daerah Aliran Sungai Alang.

\section{REKOMENDASI}

1. Data citra satelit yang digunakan adalah Landsat 7 dan Landsat 8. Alangkah lebih baik menggunakan citra Landsat 8 karena ketajaman yang lebih tinggi meskipun ukurannya lebih besar.

2. Untuk memperoleh pemetaan persebaran luas kekeringan yang sifatnya tidak memerlukan data citra secara keseluruhan tahun, dapat dipilih citra Landsat yang memiliki awan atau kabut seminimal mungkin agar pengolahan citra bisa menjadi maksimal. 


\section{UCAPAN TERIMAKASIH}

Ucapan terima kasih pertama ditujukan kepada Tuhan Yang Maha Esa atas limpahan rahmat dan nikmatnya. Selanjutnya kepada Dr. Ir. Rr. Rintis Hadiani, M.T. dan Ir. Solichin, M.T.Suryandari selaku dosen pembimbing yang telah memberi arahan dan masukan dalam penelitian ini.

\section{REFERENSI}

Adiningsih, Erna Sri. 2014. Tinjauan Metode Deteksi Parameter Kekeringan Berbasis Data Penginderaan Jauh. Pusat Teknologi dan Data Penginderaan Jauh, Lembaga Penerbangan dan Antariksa Nasional (LAPAN). Jakarta.

Anonim (2012), SNI 7745-2012 Tentang Tata Cara Perhitungan Evapotranspirasi Tanaman Acuan Dengan Metode Penman-Monteith, Badan Standardisasi Nasional.

Hadiani, Rintis. 2009. Analisis Kekeringan Berdasarkan Data Hidrologi. Program Pascasarjana Fakultas Pertanian Universitas Brawijaya. Malang.

Jamil, Dzulfikar Jamil, Heri Tjahjono, Satyanta Parman. 2013. Deteksi Potensi Kekeringan Berbasis Penginderaan Jauh dan Sistem Informasi Geografis di Kabupaten Klaten. Jurusan Geografi, Fakultas Ilmu Sosial, Universitas Negeri Semarang. Semarang.

Latuamury, Bokiraya, Totok Gunawan dan Slamet Suprayogi. 2013. Hubungan antara Indeks Vegetasi NDVI (Normalized Difference vegetation Index) dan Koefisien Resesi baseflow pada beberapa Subdas Propinsi Jawa Tengah dan Daerah Istimewa Yogyakarta. Universitas Gadjah Mada. Yogyakarta.

Manik, Tumiar Katarina, R. Bustomi Rosadi dan Agus Karyanto. 2012. Evaluasi Metode Penman-Monteith dalam Menduga Laju Evapotranspirasi Standar (ETo) di Dataran Rendah Propinsi Lampung, Indonesia. Jurusan Teknik Pertanian, Fakultas Pertanian, Universitas Lampung. Lampung.

Ningrum, Anis Puspa, Boedi Tjahjono dan Khursatul Munibah. 2015. Analisis Tingkat Kekeringan Lahan Sawah di Wilayah Bekasi Utara mengguakan Citra Landsat 7. Departemen Ilmu Tanah dan Sumberdaya Lahan, Fakultas Pertanian, Institut Pertanian Bogor. Bogor.

Prayoga, Muharrama Putra. 2017. Analisis Spasial Tingkat Kekeringan Wilayah Berbasis Penginderaan Jauh dan Sistem Informasi Geografis. Fakultas Teknik Sipil dan Perencanaan Institut Teknologi Sepuluh Nopember Surabaya. Surabaya

Raharjo, Puguh Dwi. 2010. Teknik Penginderaan Jauh dan Sistem Informasi Geografis untuk Identifikasi Potensi Kekeringan. Balai Informasi dan Konservasi Kebumian, Karangsambung, Lembaga Ilmu Pengetahuan Indonesia. Kebumen.

Purwanto, Ajun. 2015. Pemanfaatan Citra Landsat 8 untuk Identifikasi Normalized Difference Vegetation Index (NDVI) di Kecamatan Silat Hilir Kabupaten Kapuas Hulu. Program Studi Pendidikan Geografi Fakultas Ilmu Pendidikan dan Pengetahuan Sosial IKIP PGRI Pontianak, Pontianak.

Republik Indonesia. 2012. Peraturan Menteri Kehutanan Republik Indonesia Nomor : P.12/Menhut-II/2012 tentang Perubahan Kedua Atas Peraturan Pemerintah Menteri Kehutanan Nomor P.32/Menhut-II/2009 Tentang Tata Cara Penyusunan Rencana Teknik Rehabilitasi Hutan dan Lahan Daerah Aliran Sungai (Rtk RHL-DAS). Sekretariat Negara. Jakarta.

Salmani, Fakhrurrazi dan M. Wahyudi. 2013. Analisa Ketersediaan Air Daerah Aliran Sungai Barito Hulu dengan Menggunakan Debit Hasil Perhitungan NRECA. Jurusan Teknik Sipil Politeknik Negeri Banjarnasin. Banjarmasin.

Shofiyati, R, K. Honda, N.T.S. Wijesekera dan Widagdo. 2002. Pemantauan Kekeringan Lahan Pertanian Menggunakan Teknologi Remote Sensing dan SIG di DAS Brantas Hulu. Balai Besar Litbang Sumberdaya Lahan Pertanian, Bogor.

Silaban, Raymoon. 2013. Cara Membuat Peta NDVI (Normalized Difference Vegetation Index) dengan ArcGIS 10. https://raymoon760.wordpress.com/2013/07/02/cara-membuat-peta-ndvi-normalized-differencevegetation-index-dengan-arcgis-10/. (diakses tanggal 5 Januari 2018).

Sobriyah. 2012. Model Hidrologi. UPT Penerbitan dan Percetakan UNS (UNS Press). Surakarta.

Sudiana, Dodi, Elfa Diasmara. 2008. Analisis Indeks Vegetasi menggunakan Data Satelit NOAA/AVHRR dan TERRA/AQUA-MODIS. Departemen Teknik Elektro, Fakultas Teknik, Universitas Indonesia, Kampus Baru UI. Depok.

Sudinda, Teddy W. 2000. Penentuan Parameter Model NRECA untuk Pulau Natuna. Direktorat Teknologi Lingkungan, Deputi TIEML - BPPT. Jakarta.

Suwarsono, Fajar Yulianto, Parwati dan Totok Suprapto. 2009. Pemanfaatan Data Modis untuk Identifikasi Daerah Bekas Terbakar (Burned Area) Berdasarkan Perubahan Nilai NDVI di Provinsi Kalimantan Tengah Tahun 2009. Peneliti Bidang PSDAL, Pusbangja, LAPAN. 